\title{
IKZF3 wt Allele
}

National Cancer Institute

\section{Source}

National Cancer Institute. IKZF3 wt Allele. NCI Thesaurus. Code C80030.

Human IKZF3 wild-type allele is located in the vicinity of $17 q 21$ and is approximately $99 \mathrm{~kb}$ in length. This allele, which encodes zinc finger protein Aiolos, is involved in the modulation of both lymphocyte development and transcription. Genetic variation may be associated with both the occurrence and relapse of acute lymphoblastic leukemia. 